\title{
Wysokość plonów rolnych w dobrach królewskich dawnej Polski w latach 1564-1665*
}

\author{
Monika Kozłowska-Szyc \\ https://orcid.org/0000-0003-4182-2206 \\ Wydział Historii i Stosunków Międzynarodowych Uniwersytetu w Białymstoku
}

Zarys treści: Celem tego artykułu jest poznanie struktury i poziomu produkcji rolnej w folwarkach dóbr królewskich w XVI i XVII w. Należy zaznaczyć, że wysokość plonów jest jednym z najważniejszych wskaźników produktywności oraz rozwoju gospodarczego preindustrialnej Polski. Podstawą źródłową przeprowadzonych badań są lustracje królewszczyzn małopolskich, wielkopolskich, mazowieckich i podlaskich z lat 1564-1666. Wyniki analizy odsłaniają niezbyt pomyślny obraz polskiego rolnictwa. Przez cały okres obserwacji odnotowujemy duże wahania plonów, a ponadto w XVII stuleciu widoczny jest znaczny spadek wydajności czterech badanych zbóż: żyta, pszenicy, jęczmienia i owsa. Na ogół najniższym plonem charakteryzował się owies, najwydajniejszy był zaś jęczmień, a miejscami także pszenica. W XVI i XVII w. najniższe plony odnotowano w Wielkopolsce, a najwyższe - na Mazowszu i Podlasiu.

Słowa kluczowe: historia gospodarcza, wysokość plonów rolnych, lustracje dóbr królewskich

Jednym z najważniejszych wskaźników produktywności i rozwoju gospodarczego preindustrialnej Polski jest niewątpliwie wysokość plonów rolnych, co wynika przede wszystkim z agrarnego charakteru społeczeństw przednowoczesnej Europy. Oczywiste jest, że obliczenie wysokości zbiorów to niejedyny miernik poziomu ówczesnego rolnictwa. Istotne są również takie aspekty, jak system uprawy i nawożenia, zakres stosowania ugorów, struktura wysiewów, pojawianie się nowych roślin czy stosowanie skuteczniejszych narzędzi

\footnotetext{
* Publikacja sfinansowana ze środków programu ministra nauki i szkolnictwa wyższego Narodowy Program Rozwoju Humanistyki za lata 2016-2019.
}

Abstract: The aim of this article is to present the structure, size and effectiveness of agricultural production in the royal manors in the sixteenth and seventeenth centuries. It should be noted that crop yield is taken as one of the most important indicators of agricultural productivity and economic development in pre-industrial Poland. The data used in the study comes from the revisions of the royal estates (from Lesser Poland, Greater Poland, Mazovia and Podlasie region) from the years 1564-1666. Results of the analysis paint a poor picture of Polish agriculture. Throughout the whole period, we notice large fluctuations in crop yields. Furthermore, in the seventeenth century, there was a significant decrease in the yield of the four cereals: rye, wheat, barley, and oats. In general, oat was characterized by the lowest yield, while the most efficient cereals were barley and wheat. In the sixteenth and seventeenth centuries, the lowest crops were recorded in Greater Poland, the highest in Mazovia and Podlasie.

Keywords: economic history, crop yield ratio, lustrations of the royal estates

uprawy roli. Wydaje się jednak, że plon nadal pozostaje podstawowym wskaźnikiem efektywności produkcji rolnej. Obliczenie wysokości zbiorów może ponadto ukazać możliwości produkcyjne gospodarstw oraz ich wydajność, zarówno w skali mikro-, jak i makroekonomicznej.

Celem tego artykułu jest zatem poznanie poziomu produkcji rolnej w folwarkach dóbr królewskich w latach 1564-1665. Wypada w tym miejscu przypomnieć, że w XVI w. nastąpił niespotykany wcześniej rozwój gospodarczy, natomiast kolejne stulecie powszechnie uznawane jest za okres kryzysu. Pierwsza połowa XVII w. charakteryzowała się dalszym rozwojem 
gospodarki folwarcznej, druga zaś - ze względu na zniszczenia wojenne - była początkiem regresu. Zakres terytorialny obserwacji obejmuje obszar Małopolski, Wielkopolski, Mazowsza i Podlasia. Nie włączono natomiast do analizy ziem ruskich $^{1}$ ani Prus Królewskich ${ }^{2}$.

Należy zaznaczyć, że dotychczasowe polskie badania nad wysokością plonów są częścią długiej tradycji studiów z zakresu historii gospodarstwa wiejskiego ${ }^{3}$. Zagadnienie to pojawiło się $\mathrm{w}$ wielu pracach - często o bardzo różnej tematyce - już w dwudziestoleciu międzywojennym ${ }^{4}$, jednakże dopiero od lat sześćdziesiątych możemy mówić o powstaniu wyspecjalizowanego i szczegółowego nurtu badawczego, który koncentruje się na problematyce produkcji zbożowej. Wówczas to powstały liczne publikacje autorstwa m.in. Aliny Wawrzyńczykowej ${ }^{5}$, Leonida Żytkowicza ${ }^{6}$, Ireny

\footnotetext{
${ }^{1}$ Wiąże się to z wykorzystaną bazą źródłową. Lustracje ziem ruskich z lat 1564-1570 nie podają wszystkich danych niezbędnych do obliczenia współczynnika plonu (znajdujemy tu jedynie informacje 0 zbiorze w kopach), z kolei rewizja z lat 1628-1632 nie zawiera żadnych danych na temat krescencji. Zob. Lustracja województw ruskiego, podolskiego i betskiego 1564-1565, cz. 1-2, wyd. K. Chłapowski i in., Warszawa 1992-2001; Archiwum Gtówne Akt Dawnych [dalej: AGAD], Metryka Koronna [dalej: MK], dz. XVIII: Lustracje, sygn. 45, 46, 73.

Dla obszaru Prus Królewskich dysponujemy obecnie zbyt małą liczbą obserwacji (ok. 400, por. tabela 1). Wstępne analizy na tym materiale pokazały, że aby wyniki były miarodajne, należy dalej prowadzić badania źródłowe.

30 stanie badań nad wysokością plonów zob.: A. Wawrzyńczyk, Stan badań nad wysokością plonów w rolnictwie polskim XVI-XVIII w. „Kwartalnik Historii Kultury Materialnej”, 8 (1), 1960, s. 103-117; P. Guzowski, M. Kozłowska, Wysokość plonów rolnych jako wskaźnik zmian klimatu w okresie staropolskim, w: Natura Homines. Studia z historii środowiskowej, t. 1: Historia - Klimat-Przyroda. Perspektywa antropocentryczna, red. P. Oliński, W. Piasek, Toruń 2018, s. 35-47.

${ }^{4}$ R. Grodecki, Przyczynki do dziejów rolnictwa, „Tygodnik Rolniczy”, 36, 1919, s. 20-22; R. Rybarski, Handel i polityka handlowa Polski w XVI stuleciu, Poznań 1920; A. Żabko-Potopowicz, Praca najemna i najemnik w rolnictwie $w$ Wielkim Księstwie Litewskim w XVIII w. Warszawa 1929; J. Rutkowski, Badania nad podziałem dochodów w Polsce w czasach nowożytnych, t. 1, Kraków 1938.

${ }^{5}$ A. Wawrzyńczyk, Gospodarstwo dworskie w dobrach Pabianice 1559-1570, Wrocław 1967; taż, Problem wysokości plonów w królewszczyznach mazowieckich w drugiej połowie XVI i pierwszej ćwierci XVII wieku, „Studia z Dziejów Gospodarstwa Wiejskiego”, 4 (1), 1961 s. 39-130; taż, Studia nad wydajnością produkcji rolnej dóbr królewskich w drugiej połowie XVI wieku, Wrocław 1974.

${ }^{6}$ L. Żytkowicz, Studia nad gospodarstwem wiejskim $w$ dobrach kościelnych XVI w. Warszawa 1962; tenże, Ze studiów nad wysokością plonów w Polsce od XVI do XVIII wieku, „Kwartalnik Historii Kultury wych badaniach koncentrowano się głównie na okresie od połowy XVI do pierwszych dziesięcioleci XVII w., praktycznie nie zajmowano się plonami z połowy XVII stulecia ani $\mathrm{z}$ ostatniego wieku istnienia I Rzeczypospolitej. Wydaje się tymczasem, że dostępna baza źródłowa pozwala

Materialnej", 14 (3), 1966, s. 457-490; tenże, Plony zbóż w Polsce, Czechach, na Węgrzech i Stowacji w XVI-XVIII w. , ,Kwartalnik Historii Kultury Materialnej", 18 (2), 1970, s. 227-253.

${ }^{7}$ I. Rychlikowa, Studia nad towarową produkcją wielkiej własności w Małopolsce w latach 1764-1805, cz. 1: Towarowa gospodarka zbożowa, Wrocław 1966

${ }^{8}$ A. Wyczański, Plony zbóż w folwarkach królewskich województwa lubelskiego w 1564 roku, „Studia z Dziejów Gospodarstwa Wiejskiego", 4 (1) 1961, s. 17-38; tenże, 0 badaniu plonów zbóż w dawnej Polsce, „Kwartalnik Historii Kultury Materialnej”, 16 (2), 1968, s. 251-271.

${ }^{9}$ A. Mączak, Folwark pańszczyźniany a wieś w Prusach Królewskich w XVI-XVIII wieku, „Przegląd Historyczny”, 47 (2), 1956, s. 353-392; tenże, Gospodarstwo chtopskie na Żuławach Malborskich w początkach XVII wieku, Warszawa 1962.

${ }^{10} \mathrm{~J}$. Majewski, Gospodarstwo folwarczne we wsiach miasta Poznania w latach 1582-1644, Poznań 1957; B. Baranowski, Gospodarstwo chłopskie i folwarczne we wschodniej Wielkopolsce w XVIII wieku, Warszawa 1958; J. Topolski, Gospodarstwo wiejskie w dobrach arcybiskupstwa gnieźnieńskiego od XVI do XVIII wieku, Poznań 1958; W. Szczygielski, Produkcja rolnicza gospodarstwa folwarcznego w Wieluńskiem od XVI do XVIII wieku, Łódź 1963; J. Szpak, Kierunki produkcji w ekonomii malborskiej w XVI wieku, Warszawa 1972.
}

Rychlikowej $^{7}$, Andrzeja Wyczańskiego ${ }^{8}$ czy Antoniego Mączaka9. Kwestie związane z produkcją rolną podnoszono również w pracach z zakresu ogólnej historii gospodarstwa wiejskiego, które przy omawianiu poziomu rozwoju rolnictwa odnotowywały wielkość wysiewów, plonów i cen poszczególnych zbóż ${ }^{10}$. gospodarstwa wiejskiego, trzeba zdecydowanie podkreślić, że zgromadzone w nich dane źródłowe na temat wysokości plonów, choć bardzo obszerne, nierzadko są wycinkowe. Badacze próbowali uchwycić wielkość produkcji rolnej przez badania szczegółowe dotyczące pojedynczych dóbr i gospodarstw bądź całych majątków, ale w krótkim odcinku chronologicznym. Ponadto część informacji jest dość przypadkowa: natrafiając na wzmiankę źródłową o wielkości zbiorów, historycy po prostu ją odnotowywali. Co więcej, w dotychczaso-
Pisząc o stanie badań nad dziejami 
na znaczne rozszerzenie zakresu obserwacji oraz umożliwia objęcie analizą całej epoki staropolskiej. Jeżeli natomiast podejmiemy próbę zestawienia wysokości plonów w dawnej Rzeczypospolitej w oparciu o istniejące publikacje, to okaże się, że dane te są właściwie nieporównywalne. W wielu opracowaniach brakuje jednorodności przy podawaniu wskaźnika plonów. Badacze stosowali różne sposoby obliczania wielkości produkcji zbożowej, co powoduje dziś duże trudności w analizach komparatystycznych oraz prowadzeniu dalszych analiz w oparciu o zgromadzone już dane $^{11}$. Z tej przyczyny należy ponownie przeprowadzić badania źródłowe, a same informacje o produkcji rolnej zebrać według jednolitego standardu badawczego. Dużą pomoc w tej materii dają nam dziś techniki komputerowe, niedostępne w latach sześćdziesiątych i siedemdziesiątych, a więc w okresie największego rozwoju tego rodzaju badań. Z ubolewaniem należy jednak stwierdzić, że polska historiografia ostatnich dekad ogromnie zaniedbała dociekania z zakresu historii gospodarczej, a i obecnie nie cieszą się one popularnością. Wciąż brakuje kompleksowego ujęcia problematyki wielkości produkcji zbożowej w całym okresie wczesnonowożytnym. Warto więc wrócić do tematu wysokości plonów rolnych.

Analiza wielkości i efektywności produkcji zbożowej zależy w dużej mierze od stanu i rodzaju zachowanych źródeł. Dla okresu staropolskiego będą to inwentarze dóbr (starostw, dóbr biskupich i klasztornych oraz latyfundiów magnackich), rachunki zbożowe i lustracje królewszczyzn. Te ostatnie zajmują szczególne miejsce w polskiej historiografii, stanowią także podstawę wyliczenia współczynników plonów w niniejszym artykule. W opracowaniu wykorzystano rewizje dóbr królewskich

\footnotetext{
${ }^{11}$ Historycy obliczali plon na kilka sposobów: z jednego folwarku w konkretnym roku, z wielu gospodarstw w pojedynczych latach albo z jednego lub wielu majątków z kilku lat. Czasem notowali też wspólny wskaźnik dla więcej niż jednego zboża.
}

$z$ lat $1564-1565^{12}, 1569-1570^{13}, 1576^{14}$, $1602^{15}, 1616-1620^{16}, 1628-1632^{17}$ oraz $1659-1665^{18}$.

Rodzi się tu pytanie o wiarygodność informacji zawartych w lustracjach. Sceptycyzm badaczy wzbudza przede wszystkim schematyczność zapisu oraz podawanie informacji zbiorczych z kilku lat. Wynikało to z celu przeprowadzania lustracji: intencją rewizorów było ustalenie dochodowości domeny królewskiej. Nie chodziło jednak o dokładne oszacowanie poziomu dochodów dla danego roku, a raczej o uśrednione wpływy uwzględniające wszelkie wahania. Dlatego też spisujące krescencję komisje

${ }^{12}$ Lustracja województwa krakowskiego 1564, cz. 1-2, wyd. J Matocki, Warszawa 1962-1964; Lustracja województwa sandomierskiego 1564-1565, wyd. W. Ochmański, Wrocław 1963; Lustracja województwa lubelskiego 1565, wyd. A. Wyczański, Wrocław-Warszawa 1959; Lustracja województw wielkopolskich i kujawskich 1564-1565, cz. 1-2, wyd. A. Tomczak, C. Ohryzko-Włodarska, J. Włodarczyk, Bydgoszcz 1961-1963; Lustracja województwa mazowieckiego 1565, cz. 1-2, wyd. I. Gieysztorowa, A. Żaboklicka, Warszawa 1967-1968; Lustracje województwa rawskiego 1565 i 1570, wyd. Z. Kędzierska, Warszawa 1959, s. 3-147; Lustracje województwa płockiego 1565-1789, wyd. A. Sucheni-Grabowska, S.M. Szacherska, Warszawa 1965, s. 3-35.

${ }^{13}$ AGAD, MK, dz. XVIII: Lustracje, sygn. 18, 29, 44; AGAD, Archiwum Skarbu Koronnego [dalej: ASK], o. XLVI: Lustracje, rewizje i inwentarze dóbr królewskich, sygn. 103D, 143B; Lustracje województwa rawskiego 1565 i 1570, s. 153-201; Lustracje województwa płockiego, s. 36-54; Lustracje województwa podlaskiego 1570 i 1576, wyd. J. Topolski, J. Wiśniewski, Wrocław 1959.

${ }^{14}$ Tamże, S. 29-146.

${ }^{15}$ AGAD, MK, dz. XVIII, sygn. 19; Lustracje województwa rawskiego XVII wieku, wyd. Z. Kędzierska, Wrocław 1965, s. 3-34; Lustracja województwa podlaskiego 1602 roku, wyd. M. Sierba, Warszawa 2017.

${ }^{16}$ AGAD, MK, dz. XVIII, sygn. 20, 21; AGAD, ASK, o. XLVI, sygn. 46, 99B, 149; Lustracja województw wielkopolskich i kujawskich 1616-1620, cz. 1-2, wyd. Z. Górski, R. Kabaciński, J. Pakulski, Wrocław 1994; Lustracje województwa mazowieckiego XVII wieku, cz. 1: 1616-1620, wyd. A. Wawrzyńczyk, Wrocław 1968; Lustracje województwa rawskiego XVII wieku, s. 37-60; Lustracje województwa płockiego, s. 55-81. ${ }^{17}$ AGAD, MK, dz. XVIII, sygn. 22, 33; Lustracja województw wielkopolskich i kujawskich 1628-1632, cz. 1-3, wyd. Z. Guldon, Wrocław 1967-1969; Lustracje województwa rawskiego XVII wieku, s. 63-116. ${ }^{18}$ AGAD, MK, dz. XVIII, sygn. 66; Lustracja województwa krakowskiego 1659-1664, cz. 1-3, wyd. A. Falniowska-Gradowska, F. Leśniak, Warszawa 2005; Lustracja województwa sandomierskiego 1660-1664, cz. 1-2, wyd. H. Oprawko, K. Schuster, Kraków 1971-1977; Lustracja województwa lubelskiego 1661, wyd. H. Oprawko, K. Schuster, Warszawa 1962; Lustracja województw wielkopolskich i kujawskich 1659-1665, cz. 1, wyd. C. Ohryzko-Włodarska, Wrocław 1978; Lustracja województw wielkopolskich i kujawskich 1659-1665, cz. 2, wyd. Z. Górski, J. Pak, Toruń 1996; Lustracje województwa mazowieckiego XVII wieku, cz. 2: 1660-1661, wyd. A. Wawrzyńczyk, Warszawa 1989; Lustracje województwa rawskiego XVII wieku, s. 119-218; Lustracje województwa płockiego, s. 82-127. 
lustratorskie opierały się na informacjach zebranych z kilku ostatnich lat (najczęściej trzech poprzedzających moment dokonywania lustracji). Współczynnik plonu obliczony na podstawie tego źródła będzie zatem wskaźnikiem uśrednionym, ale zarazem rzeczywistym i zgodnym z ówczesnymi realiami gospodarowania. Wydaje się także, że większość współczynników plonów mieści się w przedziałach bliskich wartości średniej, która jest najbardziej sumarycznym miernikiem poziomu zbiorów, a przez to jednym z najważniejszych wskaźników rozwoju rolnictwa. Ponadto lustracje są źródłem masowym, charakteryzującym się dużą jednorodnością. Materiał ten podaje szereg szczegółowych informacji dotyczących folwarcznej produkcji rolnej z okresu od połowy XVI do końca XVIII stulecia ${ }^{19}$. Co więcej, źródło to odnosi się do rozległych obszarów rozrzuconych po całym terenie ówczesnego państwa, obejmując swoim zasięgiem ok. 10 proc. własności ziemskiej dawnej Polski ${ }^{20}$.

Źródła o charakterze inwentarzowym oferują materiał wybitnie masowy, wymagający wykorzystania odpowiednio dostosowanych narzędzi badawczych. Trzon analizy opiera się zatem o metody kwantytatywne, które nadal są rzadko wykorzystywane w polskiej historiografii ${ }^{21}$. W niniejszym artykule posłużono się takimi miarami jak mediana, kwartyle ${ }^{22}$ oraz regresja LOESS ${ }^{23}$, którą można traktować jako połączenie regresji liniowej i średniej ruchomej, jednak w przeciwieństwie do

\footnotetext{
${ }^{19}$ Zgodnie z postanowieniami sejmu piotrkowskiego (1562-1563) lustracje miały się odbywać co pięć lat, jednak dla ogółu królewszczyzn przeprowadzono je w latach: 1564-1565, 1569-1570, 1615-1620, 1628-1632, 1659-1665, 1764-1765 i 1788-1789, a dla części dóbr w latach: 1602, 1606, 1624 i 1636.

${ }^{20}$ A. Wawrzyńczyk, Studia, s. 11-12.

${ }^{21}$ P. Guzowski, R. Poniat, Miejsce badań kwantytatywnych we wspótczesnej historiografii polskiej, „Rocznik Dziejów Społecznych i Gospodarczych", 73, 2013, s. 243-255.

22 Już Andrzej Wyczański wskazywał na dużą wagę wspomnianych wyżej mierników statystycznych, które obrazują najważniejszą część rozrzutu plonów, pomijając dane skrajne. A. Wyczański, 0 badaniu, s. 258-259.

${ }^{23} 0$ regresji LOESS zob. R. Poniat, 0 możliwości wykorzystania regresji LOESS w analizie szeregów czasowych, „Przeszłość Demograficzna Polski", 38 (2), 2016, s. 103-115.
}

tych wskaźników jest ona względnie odporna na braki danych w szeregu czasowym. Poddawane analizie dane zebrano w bazie zawierającej informacje odnoszące się do wielkości produkcji rolnej (m.in. zbiór w kopach, omłot i wysiew). Na podstawie tych danych obliczony został współczynnik wysokości plonów, który zaprezentowano pod postacią tzw. ziarna (cropyield ratio). Metoda ta wyraża stosunek ilości ziarna zebranego do ilości ziarna wysianego. Jej główną zaletą jest unikanie ustaleń metrologicznych, które mogą prowadzić do zniekształcenia otrzymanych wyników. Jest to ważne, ponieważ znajomość objętości dawnych miar nasypowych nadal jest niewystarczająca - nie możemy być pewni ich wielkości m.in. ze względu na różne zwyczajowe sposoby mierzenia ${ }^{24}$. Ponadto metoda ta wskazuje na stopień produkcji rolnej bez odwołania się do obszaru, z jakiego zebrano zboże. Źródła zazwyczaj nie podają powierzchni zasiewów, a co więcej, nie znamy ówczesnych norm gęstości wysiewu poszczególnych zbóż, dlatego taki sposób wyliczania znacząco redukuje ryzyko błędnego wnioskowania ${ }^{25}$.

W analizie brano pod uwagę plon jednostkowy, a więc wydajność ziarna z jednego gospodarstwa i jednego roku, gdyż to ten wskaźnik najlepiej odzwierciedla rzeczywistość. Nie wykorzystano zaś wskaźników grupowych, czyli współczynników plonu z kilku folwarków w konkretnym roku bądź z jednego lub wielu gospodarstw w kilku latach. Liczbę wykorzystanych wskaźników ukazuje tabela 1 . Należy stwierdzić, że reprezentowane są tu prawie wszystkie dzielnice dawnej Rzeczypospolitej, ale w nierównym stopniu. Największą liczbę współczynników odnotowano w Małopolsce, najmniejszą zaś

\footnotetext{
${ }^{24}$ Zob. K. Skupieński, Struktury systemowe polskich miar zbożowych w XVI wieku, „Przegląd Historyczny”, 69 (4) 1978, s. 623-646.

${ }^{25}$ W literaturze podjęto próby ustalenia norm gęstości wysiewu, jednak wahały się one w różnych okresach i terenach zależnie od rodzaju gleby, zwyczajów, wilgotności czy zasobów ziarna. Zob. I. Rychlikowa, W sprawie modernizacji warsztatu historyka rolnictwa, „Kwartalnik Historii Kultury Materialnej", 16 (1), 1968, s. 7.
} 
Tabela 1. Liczba wskaźników plonów czterech głównych zbóż w latach 1564-1665

\begin{tabular}{|c|c|c|c|c|c|c|c|}
\hline \multirow[b]{2}{*}{ Region } & \multicolumn{6}{|c|}{ Rok } & \multirow[b]{2}{*}{ Razem } \\
\hline & $1564-1565$ & $\begin{array}{c}1569-1570 \\
\left(1576^{*}\right)\end{array}$ & 1602 & $1616-1620$ & $1628-1632$ & $1659-1665$ & \\
\hline Małopolska & 636 & 531 & 130 & 207 & 329 & 897 & 2730 \\
\hline Wielkopolska & 356 & 337 & - & 226 & 36 & 518 & 1473 \\
\hline Mazowsze i Podlasie & 395 & 248 & 79 & 404 & 78 & 304 & 1508 \\
\hline Razem & 1387 & 1116 & 209 & 837 & 443 & 1719 & 5711 \\
\hline
\end{tabular}

Źródło: obliczenia własne

w Wielkopolsce. Mazowsze i Podlasie rozpatrywane są natomiast łącznie, co wynika ze zbyt małej liczby obserwacji (zwłaszcza na Podlasiu) i podobnych warunków gospodarowania.

Najważniejszy dział produkcji folwarcznej stanowiły uprawy roślinne. Ich różnorodność była stosunkowo duża, jednakże przez cały okres wczesnonowożytny największe znaczenie miały zboża. Na pierwszym miejscu plasowało się żyto, następnie owies, jęczmień i pszenica. Dużo mniej siano zaś grochu ${ }^{26}$, prosa czy gryki, którą w źródłach często nazywano tatarką, hreczką bądź poganką. Zawarte w artykule rozważania ograniczone są do czterech podstawowych zbóż: żyta, pszenicy, jęczmienia i owsa, co wynika z dużo większej dochodowości tych upraw oraz ich ogromnego znaczenia w gospodarce folwarcznej.

Opis produkcji zbożowej należy zacząć od krótkiego omówienia struktury zasiewów (zob. wykres 1). Największe znaczenie gospodarcze miało żyto, które uprawiano we wszystkich częściach dawnej Polski, przede wszystkim jako zboże ozime (jako jare siano je bardzo rzadko) ${ }^{27}$. Zajmowało ono także stosunkowo największy obszar uprawny. Choć w niektórych regionach (np. w Małopolsce)

\footnotetext{
${ }^{26}$ W omawianym okresie groch stanowił już uprawę polową, a nie ogrodową.

${ }^{27}$ Tzw. jarka odgrywała uboczną rolę w zasiewach i zbiorach. Wydaje się, że nie chodziło 0 inną odmianę żyta, a raczej 0 dosiewanie żyta jarego do zasiewów zimowych. Skromne informacje źródłowe na ten temat nie pozwalają jednak na wysnucie głębszych wniosków.
}

nieznacznie większy był wysiew owsa, to jednak w skali całego kraju właśnie żyto plasowało się na pierwszym miejscu. Najwięcej tego zboża uprawiano na Mazowszu i Podlasiu, gdzie stanowiło nieco ponad 50 proc. wysiewu.

Również pszenica uprawiana była na terenie całej Rzeczypospolitej, ale nie we wszystkich folwarkach. Zboże to wysiewano głównie jako oziminę, choć czasami - podobnie jak żyto - jako jare. Należy jednak zaznaczyć, że udział pszenicy w uprawach był niewielki (od zaledwie 3 proc. do maksymalnie 10 proc.), a plon w dużej mierze zależał od warunków naturalnych. Pszenica wymagała lepszych gleb i staranniejszej pracy. Stosunkowo poważne miejsce zajmowała w uprawach małopolskich i wielkopolskich, najmniejszy jej procent odnotowano zaś na Mazowszu i Podlasiu.

Jęczmień siany był wiosną jako zboże jare i podobnie jak pszenica potrzebował lepszych gleb. Jego udział w uprawach był niewielki, na ogół ok. 8 proc. Owies charakteryzował się z kolei pokaźnym udziałem w strukturze zasiewów - zajmował dużo większą część pola jarego. Było to zboże mało wymagające, przeznaczane głównie na paszę dla inwentarza żywego.

Interesującą kwestią są także zmiany struktury zasiewów w czasie. Przede wszystkim przez cały okres obserwacji maleje wysiew owsa, a wzrasta znaczenie jęczmienia, co wiąże się z rozwojem browarnictwa. Miejscami (na Mazowszu i Podlasiu) rośnie 

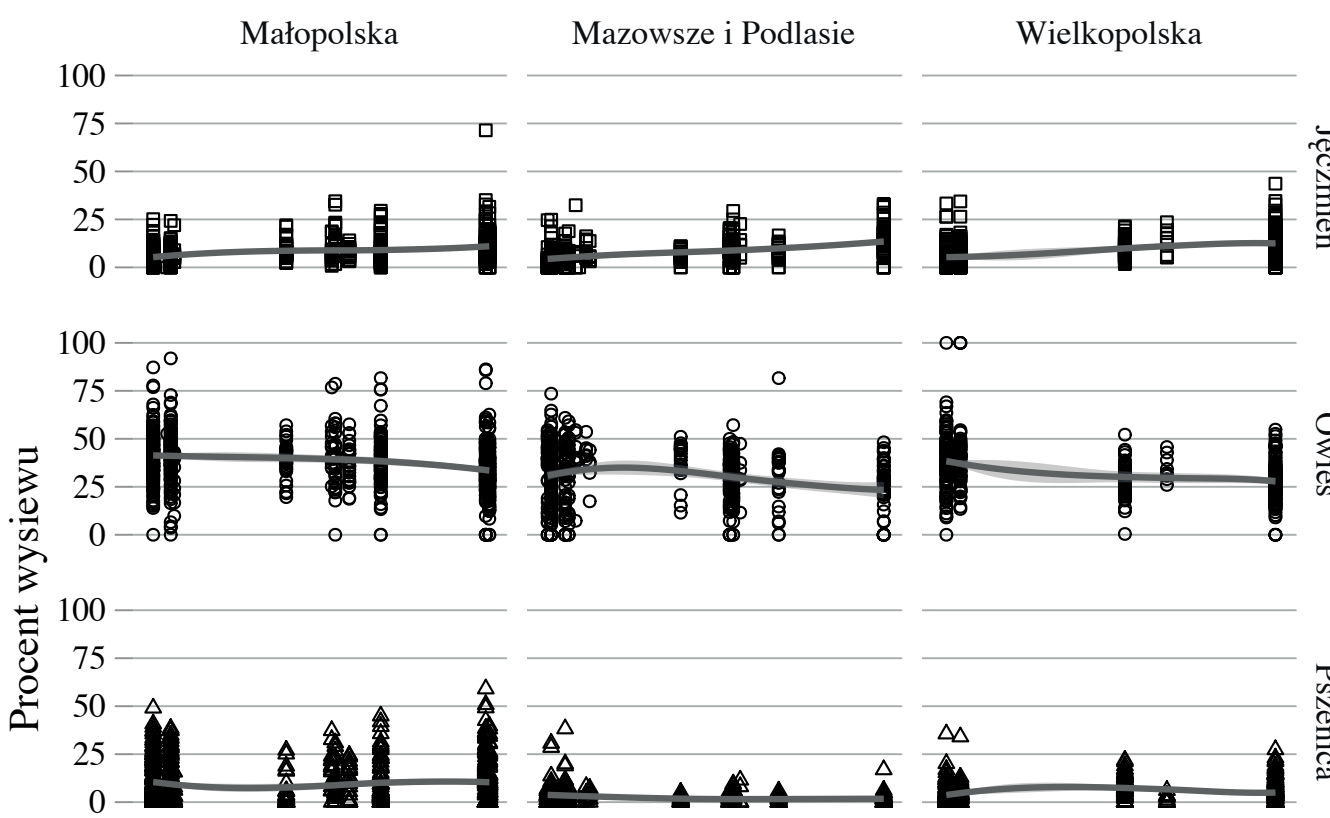

○
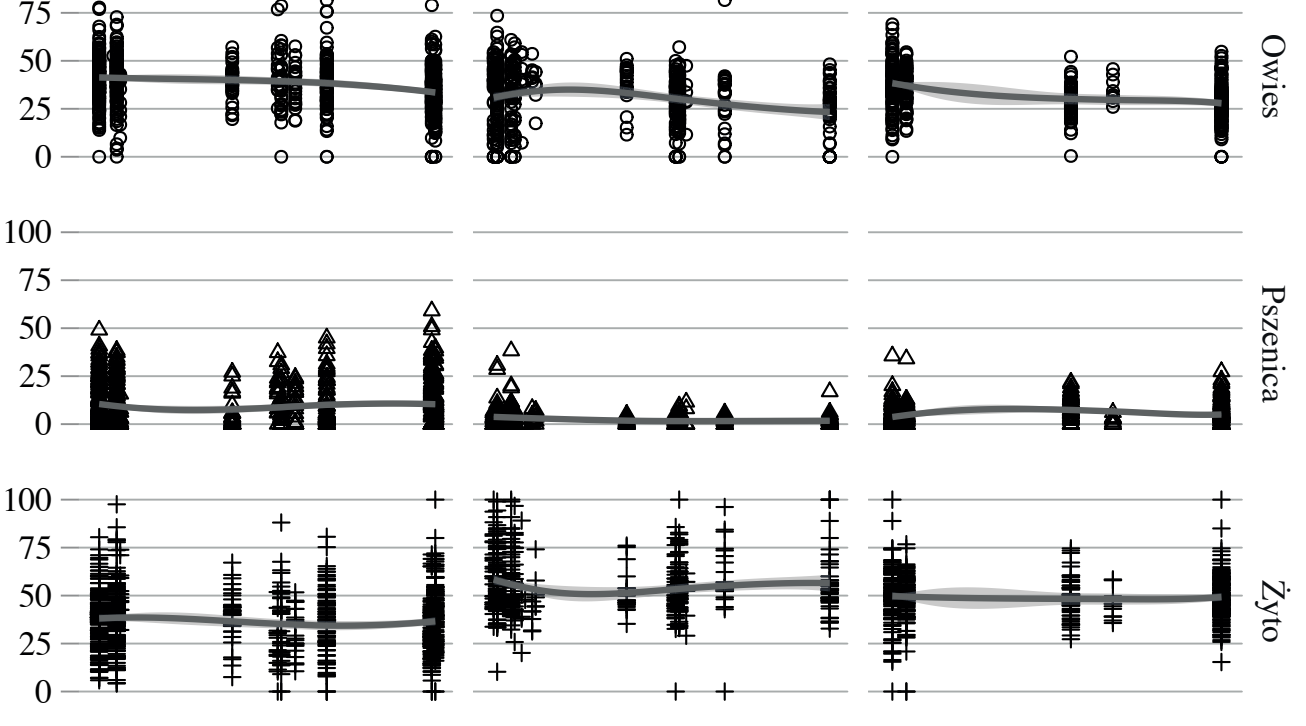

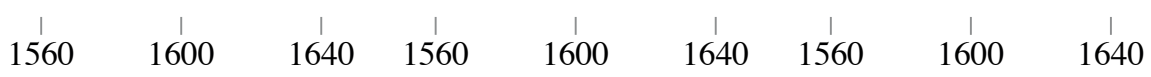

Wykres 1. Struktura wysiewu czterech zbóż w poszczególnych regionach Rzeczypospolitej w latach 1564-1666.

Kwadratami, kołami, trójkątami i plusami oznaczono wszystkie obserwacje w poszczególnych regionach dawnej Polski; szara linia prezentuje regresję LOESS, a jasnoszare tto - zakres niepewności regresji.

Źródto: obliczenia własne

także udział żyta i pszenicy (w Małopolsce). Uogólniając, można jednak stwierdzić, że przedstawiona struktura wysiewów była typowa dla epoki staropolskiej: charakteryzowała się znaczną przewagą żyta oraz marginalną uprawą pszenicy. Znaczna zmiana struktury zasiewów nastąpiła dopiero w okresie, gdy na szerszą skalę wprowadzono nowe rośliny uprawne (m.in. okopowe).

Jak już wspomniano, jednym $z$ istotniejszych wskaźników poziomu rolnictwa w preindustrialnej Polsce jest wysokość plonów. Rozmiar produkcji zbożowej był wypadkową wielu czynników, nie tylko ekonomicznych i technicznych, ale także przyrodniczych. Zależał m.in. od jakości gleb, warunków pogodowych czy też położenia.

$\mathrm{Na}$ wykresach 2-4 przedstawiono rozkład plonów w czasie w omawianych regionach dawnej Rzeczypospolitej; dla poszczególnych lat wyliczono medianę, kwartyle oraz wartości minimalne i maksymalne ${ }^{28}$. Omawianie wielkości zbiorów rolnych

\footnotetext{
${ }^{28} \mathrm{Na}$ temat wykresów pudełkowych zob. R. Poniat, 0 wykorzystaniu wykresów pudetkowych do prezentacji danych demograficznych i o pożytku z użycia środowiska $R$ z pakietem ggplot2, „Przeszłość Demograficzna Polski", 34, 2014, s. 103-120.
} 


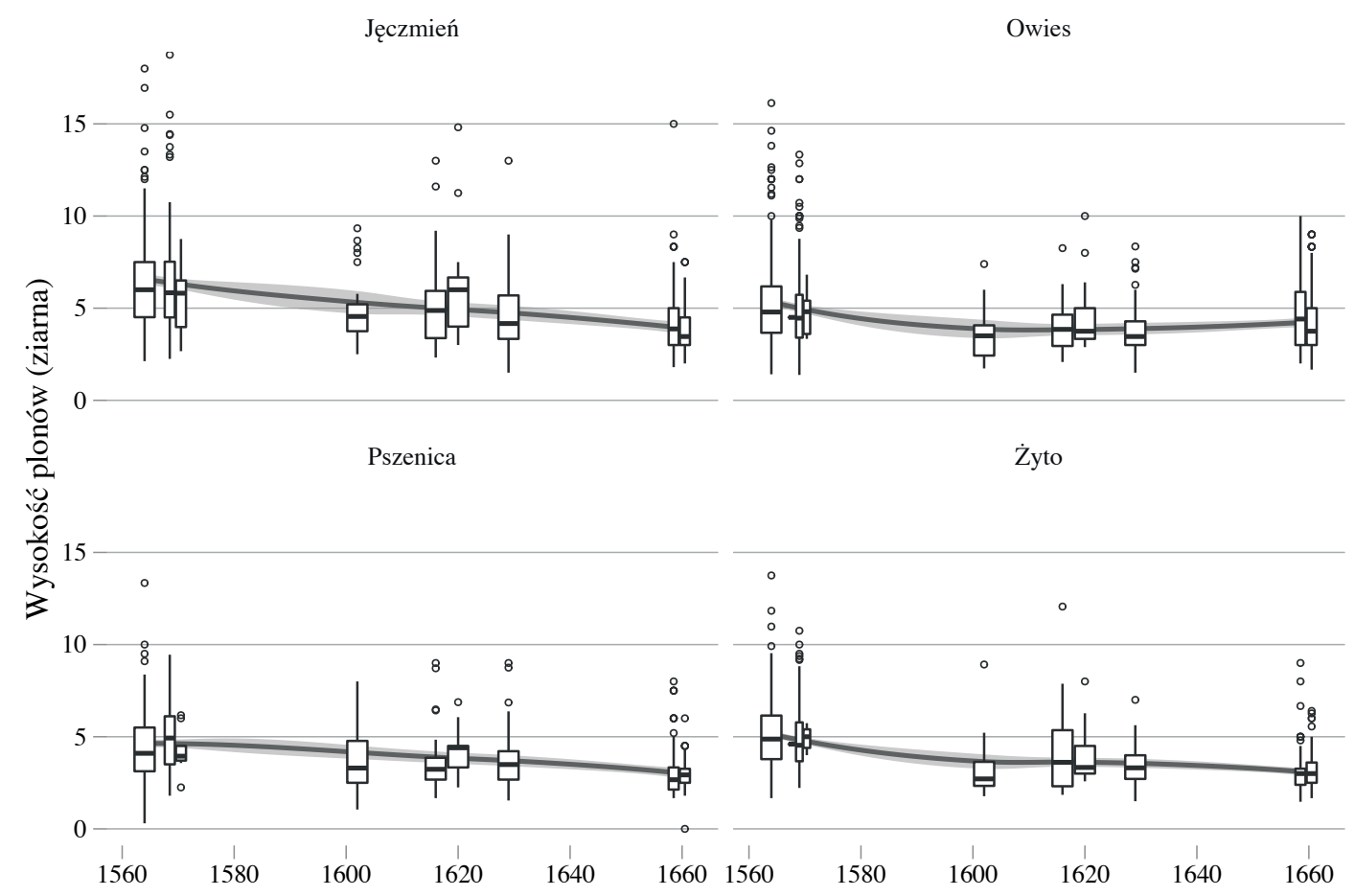

Wykres 2. Wysokość plonów czterech zbóż w Małopolsce w latach 1564-1666.

Szara linia prezentuje regresję LOESS, a jasnoszare to - zakres niepewności regresji.

Źródło: obliczenia własne

zaczniemy od Małopolski (wykres 2). Pierwszą rzeczą, która zwraca uwagę, jest duże rozproszenie współczynników plonów czterech zbóż, szczególnie w drugiej połowie XVI w., kiedy obserwujemy znaczne wahania plonów oraz dużą liczbę wskaźników skrajnych. Kolejne stulecie charakteryzuje się już mniejszymi wahaniami, ale i spadkiem plonów. Należy także zaznaczyć, że najlepszą wydajnością cechował się jęczmień - w XVI w. osiągał wartość 6 ziaren (mediana), ale już w 1602 r. jego plon obniżył się, by następnie nieznacznie wzrosnąć, a w drugiej połowie XVII stulecia ponownie spaść (mediana: 3,5 ziarna). Dużo mniej korzystnie wypadła pszenica, której wydajność przez cały okres obserwacji kształtowała się na podobnym poziomie co plon żyta i owsa (mediana: 4,5-5 ziaren w XVI w., od 3 do ok. 3,5 w kolejnym stuleciu). Warto jednak odnotować, że pszenica osiągnęła także najniższą wartość minimalną - często spadała poniżej 2 ziaren, a w 1564 r. jej wartość była bliska zeru. Dużo trudności sprawia precyzyjne określenie, przy jakim plonie występował niedobór zboża, jednak z całą pewnością można stwierdzić, że na poziomie 2 ziaren i mniej stanowił już klęskę nieurodzaju. Minimalną granicą opłacalności była wydajność na poziomie 3 ziaren.

Na Mazowszu i Podlasiu (wykres 3) obserwujemy jeszcze większe wahania plonów czterech zbóż, o czym świadczą duże rozstępy ćwiartkowe oraz występowanie obserwacji skrajnych, znacząco oddalonych od przeciętnej wysokości zbiorów. Rozrzut współczynników, podobnie jak w Małopolsce, szczególnie widoczny jest w drugiej połowie XVI stulecia. Zauważalna jest tu 


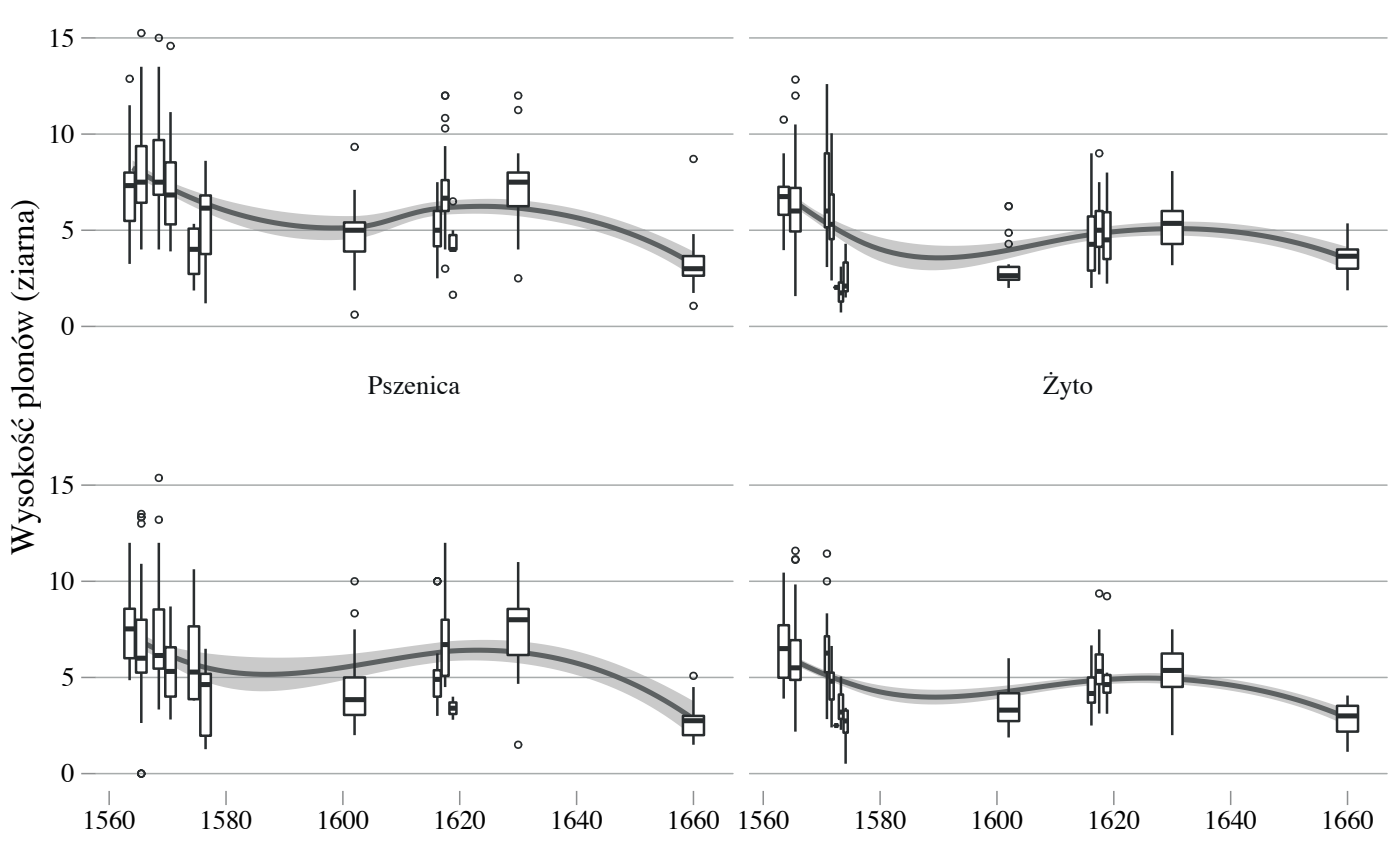

Wykres 3. Wysokość plonów czterech zbóż na Mazowszu i Podlasiu w latach 1564-1666.

Szara linia prezentuje regresję LOESS, a jasnoszare tto - zakres niepewności regresji.

Źródto: obliczenia własne

jednak inna tendencja niż we wcześniej omówionym regionie. Przede wszystkim wskaźnik plonu czterech zbóż w świetle pierwszej i drugiej lustracji jest bardzo wysoki - mediana żyta kształtuje się na poziomie powyżej 6 ziaren, pszenicy - od 6 do 7,5, jęczmienia - ok. 7,5, a owsa - od 5 do 6,5 ziarna. W 1576 oraz 1602 r. nastąpił z kolei znaczny spadek wydajności wszystkich omawianych zbóż, zwłaszcza owsa i żyta. Dalej, w latach 1616-1620 oraz 1628-1632, wysokość plonu wzrosła, a wyższe wartości osiągały jęczmień (mediana nawet do 7 ziaren) i pszenica (mediana: 8 ziaren). Zboża te charakteryzowała także skrajnie różna wielkość plonów. Ostatecznie w drugiej połowie XVII w. notujemy znaczny spadek plonu wszystkich zbóż (do ok. 3-3,5 ziarna). Należy także zaznaczyć, że na tle pozostałych regionów Mazowsze i Podlasie cechowała najwyższa wydajność zbiorów, w szczególności jęczmienia, którego plon maksymalny w XVI w. osiągał wartość przekraczającą 13 ziaren.

Najniższą wartość współczynnika plonu spostrzegamy z kolei w Wielkopolsce (wykres 4). Co prawda w drugiej lustracji produkcja rolna wypadła nieco korzystniej niż w pierwszej, jednak nadal pozostawała na niższym poziomie niż $\mathrm{w}$ innych prowincjach. Wyraźny wzrost zauważono dopiero w XVII w., choć wielkopolska lustracja z lat 1616-1620 charakteryzowała się pewnym schematyzmem - komisja lustratorska przyjęła tu zapewne jakiś wzorzec w podawaniu stosunku omłotu do wysiewu, ponieważ w większości folwarków plon obliczony na podstawie tych danych wynosi 5 ziaren. W kolejnych latach XVII w. obserwujemy spadek wydajności (mediana: 3-3,5 ziarna). W Wielkopolsce najwyższy 


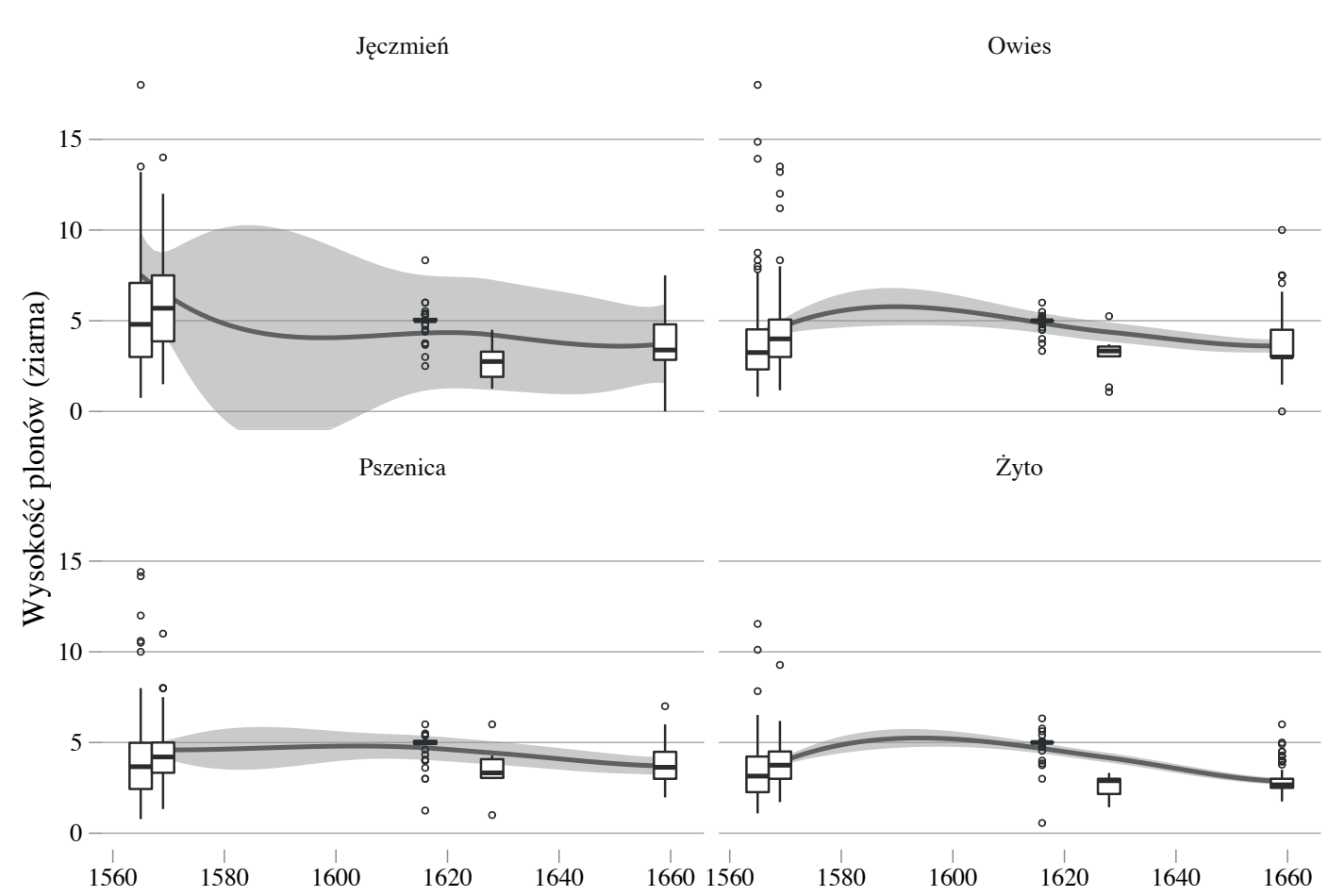

Wykres 4. Wysokość plonów czterech zbóż w Wielkopolsce w latach 1564-1666.

Szara linia prezentuje regresję LOESS, a jasnoszare tto - zakres niepewności regresji.

Żródto: obliczenia własne

plon osiągał jęczmień, a pszenica, żyto i owies dawały podobne zbiory. W regionie tym zauważamy także mniejszy rozrzut współczynników, a co za tym idzie mniejsze wahania wielkości zbiorów.

Podsumowując, można stwierdzić, że nawet na podstawie wartości uśrednionych - bo za takie należy uznać dane o plonach z lustracji - zauważamy sporą rozpiętość wskaźników plonów. Dużym rozrzutem wartości zbiorów charakteryzował się przede wszystkim wiek XVI i w tym też okresie odnotowujemy pokaźną liczbę obserwacji skrajnych. W kolejnym stuleciu wahania plonów były już mniejsze. Na każdym wykresie widoczna jest ponadto tendencja spadkowa: najniższą wartość plony wszystkich zbóż osiagają w latach sześćdziesiątych XVII stulecia, co związane jest oczywiście ze zniszczeniami wojennymi. Samo zagadnienie zmienności i skoków plonów jest jednak bardziej skomplikowane, niż mogłoby się wydawać. Duże wahania zbiorów oznaczały niepewność wyników produkcji rolnej. Nie możemy jednak tłumaczyć tego zjawiska tylko i wyłącznie niskim poziomem technicznym rolnictwa czy zniszczeniami wojennymi. W pewnej mierze musiały na to wpływać pogarszające się warunki pogodowe, ale również sam sposób rejestracji produkcji rolnej. Należy zaznaczyć, że pierwsza i druga lustracja królewszczyzn charakteryzowały się największą dokładnością, a tym samym najlepiej odzwierciedlają ówczesną rzeczywistość. Rewizja wielkopolska z lat 1616-1620 przyjęła natomiast określoną wysokość plonów arbitralnie. Kwestie te wymagają oczywiście dalszych, bardziej szczegółowych badań źródłoznawczych.

Pisząc o poszczególnych uprawach, należy wspomnieć jeszcze, że owies charakte- 
ryzował się na ogół niższym plonem, najwydajniejszy był zaś jęczmień, a miejscami także pszenica. Lepsze zbiory tych ostatnich zbóż należy tłumaczyć staranniejszą uprawą, przede wszystkim w dużo mniejszych ilościach niż w przypadku żyta i owsa, co pozwalało na przeznaczenie pod nie lepszych części pola. Najniższy plon ze wszystkich czterech zbóż odnotowano w Wielkopolsce, najwyższy zaś na Mazowszu i Podlasiu. Ta ostatnia informacja jest dość zaskakująca, gdyż w rejonie tym gleby były gorszej jakości niż w innych prowincjach dawnej Rzeczypospolitej. Tak wysoki zbiór mógł wynikać ze sposobu rejestracji - możliwe, że mazowieccy lustratorzy zbyt optymistycznie ocenili wydajność tamtejszych folwarków.

Wyniki powyższej analizy odsłaniaja niezbyt pomyślny obraz polskiego rolnictwa. Pozostaje zadać sobie pytanie, czy jest on zgodny w ówczesnymi realiami. W artykule wykorzystano ponad 5,7 tys. współczynników plonów, czyli stosunkowo pokaźną liczbę danych, jednak obejmują one niewielki odsetek istniejących wówczas gospodarstw. W dalszych badaniach należałoby zwiększyć liczbę wskaźników i uwzględnić wszystkie dzielnice dawnej Rzeczypospolitej. Ponadto kolejne analizy powinny koncentrować się na jeszcze jednym aspekcie, a mianowicie kwestiach związanych ze środowiskiem i klimatem. Polscy badacze niską wydajność rolnictwa oraz spadek wysokości plonów wiązali głównie z kryzysem systemu folwarczno-pańszczyźnianego, nie odwołując się bezpośrednio do warunków klimatycznych i przyrodniczych. Tymczasem w ostatnich latach zwrócono szczególną uwagę na problematykę konsekwencji zmian klimatu w Europie Środkowej i Wschodniej. Geoffrey Parker w swojej głośnej książce o globalnym kryzysie XVII w. wskazał na państwo polsko-litewskie jako przykład kraju szczególnie dotkniętego przez wojny i małą epokę lodowcową 29 . W tę ogólną narrację o kryzysach politycznych, gospodarczych i demograficznych występujących w okresie ochładzania się klimatu wpisują się również prace innych badaczy ${ }^{30}$. Trzeba w tym miejscu podkreślić, że rozwój ekonomiczny Rzeczypospolitej na początku epoki nowożytnej, a następnie kryzys (nie tylko polityczny, ale również gospodarczy), który dotykał kraj w XVII i XVIII w., przypadały właśnie na czas małej epoki lodowcowej. Ponadto zasadniczy zrąb źródeł rejestrujący wielkość produkcji rolnej pochodzi z XVI-XVIII w., więc w całości mieści się w okresie wyraźnego oziębienia klimatu. W związku z tym badania nad wysokością plonów mogą być z powodzeniem wykorzystywane w dalszych analizach, dotyczących m.in. wpływu zmian klimatu na gospodarkę. Wydaje się także, że społeczeństwo dawnej Rzeczypospolitej jest idealnym przykładem do analizowania strategii adaptacyjnych wobec różnego rodzaju ekstremalnych zjawisk pogodowych i klęsk naturalnych (poprzez badania struktury zasiewów). Należy więc ponownie zająć się problematyką produkcji rolnej i dokonać próby powiązania historycznych danych o plonach $\mathrm{z}$ informacjami na temat klimatu.

\footnotetext{
${ }^{29}$ G. Parker, Global crisis. War, climate change and catastrophe in the seventeenth century, Padstow 2013, s. 508.

$30 \mathrm{U}$. Büntgen i in., Filling the Eastern European gap in millenium-long temperature reconstructions, „Proceedings of the National Academy of Sciences of the United States of America”, 110, 2013, s. 1773-1778.
} 


\section{Bibliografia}

\section{Źródła publikowane}

Lustracja województw ruskiego, podolskiego i betskiego 1564-1565, cz. 1-2, wyd. K. Chłapowski, H. Żytkowicz, red. L. Żytkowicz, A. Falniowska-Gradowska, Warszawa 1992-2001.

Lustracja województw wielkopolskich i kujawskich 1564 1565, cz. 1-2, wyd. A. Tomczak, C. Ohryzko-Włodarska, J. Włodarczyk, Bydgoszcz 1961-1963.

Lustracja województw wielkopolskich i kujawskich 1616-1620, cz. 1-2, wyd. Z. Górski, R. Kabaciński, J. Pakulski, Wrocław 1994.

Lustracja województw wielkopolskich i kujawskich 1628-1632, cz. 1-3, wyd. Z. Guldon, Wrocław 1967-1969.

Lustracja województw wielkopolskich i kujawskich 1659-1665, cz. 1, wyd. C. Ohryzko-Włodarska, Wrocław 1978.

Lustracja województw wielkopolskich i kujawskich 16591665, cz. 2, wyd. Z. Górski, J. Pak, Toruń 1996.

Lustracja województwa krakowskiego 1564, cz. 1-2, wyd. J. Małecki, Warszawa 1962-1964.

Lustracja województwa krakowskiego 1659-1664, cz. 1-3, wyd. A. Falniowska-Gradowska, F. Leśniak, Warszawa 2005.

Lustracja województwa lubelskiego 1565, wyd. A. Wyczański, Wrocław-Warszawa 1959.

Lustracja województwa lubelskiego 1661, wyd. H. Oprawko, K. Schuster, Warszawa 1962.

\section{Literatura}

Baranowski B., Gospodarstwo chtopskie i folwarczne we wschodniej Wielkopolsce w XVIII wieku, Warszawa 1958.

Büntgen U., Kyncl T., Ginzler Ch., Jacks D.S., Esper J., Tegel W., Heussner K., Kyncl J., Filling the Eastern European gap in millenium-long temperature reconstructions, „Proceedings of the National Academy of Sciences of the United States of America", 110, 2013, s. 1773-1778.

Grodecki R., Przyczynki do dziejów rolnictwa, „Tygodnik Rolniczy", 36, 1919, s. 20-22.

Guzowski P., Kozłowska M., Wysokość plonów rolnych jako wskaźnik zmian klimatu w okresie staropolskim, w: Natura Homines. Studia z historii środowiskowej, t. 1: Historia - Klimat-Przyroda. Perspektywa antropocentryczna, red. P. Oliński, W. Piasek, Toruń 2018, s. 35-47.

Guzowski P., Poniat R., Miejsce badań kwantytatywnych we wspótczesnej historiografii polskiej, „Rocznik Dziejów Społecznych i Gospodarczych”, 73, 2013, s. 243-255.
Lustracja województwa mazowieckiego 1565, cz. 1-2, wyd. I. Gieysztorowa, A. Żaboklicka, Warszawa 1967-1968.

Lustracja województwa podlaskiego 1602 roku, wyd. M. Sierba, Warszawa 2017.

Lustracja województwa sandomierskiego 1564-1565, wyd. W. Ochmański, Wrocław 1963.

Lustracja województwa sandomierskiego 1660-1664, cz. 1-2, wyd. H. Oprawko, K. Schuster, Kraków 1971-1977.

Lustracje województwa mazowieckiego XVII wieku, cz. 1: 1616-1620, wyd. A. Wawrzyńczyk, Wrocław 1968.

Lustracje województwa mazowieckiego XVII wieku, cz. 2: 1660-1661, wyd. A. Wawrzyńczyk, Warszawa 1989.

Lustracje województwa ptockiego 1565-1789, wyd. A. Sucheni-Grabowska, S.M. Szacherska, Warszawa 1965.

Lustracje województwa podlaskiego 1570 i 1576, wyd. J. Topolski, J. Wiśniewski, Wrocław 1959.

Lustracje województwa rawskiego 1565 i 1570, wyd. Z. Kędzierska, Warszawa 1959.

Lustracje województwa rawskiego XVII wieku, wyd. Z. Kędzierska, Wrocław 1965.

Majewski J., Gospodarstwo folwarczne we wsiach miasta Poznania w latach 1582-1644, Poznań 1957.

Mączak A., Folwark pańszczyźniany a wieś w Prusach Królewskich w XVI-XVIII wieku, „Przegląd Historyczny”, 47 (2), 1956, s. 353-392.

Mączak A., Gospodarstwo chtopskie na Żutawach Malborskich w początkach XVII wieku, Warszawa 1962.

Natura Homines. Studia z historii środowiskowej, t. 1: Historia - Klimat - Przyroda. Perspektywa antropocentryczna, red. P. Oliński, W. Piasek, Toruń 2018.

Parker G., Global crisis. War, climate change and catastrophe in the seventeenth century, Padstow 2013.

Poniat R., O możliwości wykorzystania regresji LOESS $w$ analizie szeregów czasowych, „Przeszłość Demograficzna Polski”, 38 (2), 2016, s. 103-115.

Poniat R., O wykorzystaniu wykresów pudetkowych do prezentacji danych demograficznych i o pożytku z użycia środowiska $R$ z pakietem ggplot2, „Przeszłość Demograficzna Polski”, 34, 2014, s. 103-120.

Rutkowski J., Badania nad podziatem dochodów w Polsce $w$ czasach nowożytnych, t. 1, Kraków 1938. 
Rybarski R., Handel i polityka handlowa Polski w XVI stuleciu, Poznań 1920.

Rychlikowa I., Studia nad towarowa produkcja wielkiej wtasności w Matopolsce w latach 1764-1805, cz. 1: Towarowa gospodarka zbożowa, Wrocław 1966.

Rychlikowa I., W sprawie modernizacji warsztatu historyka rolnictwa, „Kwartalnik Historii Kultury Materialnej”, 16 (1), 1968, s. 3-37.

Skupieński K., Struktury systemowe polskich miar zbożowych w XVI wieku, „Przegląd Historyczny”, 69 (4), 1978, s. 623-646.

Szczygielski W., Produkcja rolnicza gospodarstwa folwarcznego w Wieluńskiem od XVI do XVIII wieku, Łódź 1963.

Szpak J., Kierunki produkcji w ekonomii malborskiej w XVI wieku, Warszawa 1972.

Topolski J., Gospodarstwo wiejskie w dobrach arcybiskupstwa gnieźnieńskiego od XVI do XVIII wieku, Poznań 1958.

Wawrzyńczyk A., Gospodarstwo dworskie w dobrach Pabianice 1559-1570, Wrocław 1967.

Wawrzyńczyk A., Problem wysokości plonów w królewszczyznach mazowieckich $w$ drugiej potowie XVI i pierwszej ćwierci XVII wieku, „Studia z Dziejów Gospodarstwa Wiejskiego”, 4 (1), 1961, s. 39-130.

Wawrzyńczyk A., Stan badań nad wysokościa plonów $w$ rolnictwie polskim XVI-XVIII $w$., „Kwartal- nik Historii Kultury Materialnej”, 8 (1), 1960 , s. $103-117$.

Wawrzyńczyk A., Studia nad wydajnościa produkcji rolnej dóbr królewskich w drugiej potowie XVI wieku, Wrocław 1974.

Wyczański A., O badaniu plonów zbóż w dawnej Polsce, „Kwartalnik Historii Kultury Materialnej”, 16 (2), 1968, s. 251-271.

Wyczański A., Plony zbóż w folwarkach królewskich województwa lubelskiego w 1564 roku, „Studia z Dziejów Gospodarstwa Wiejskiego”, 4 (1) 1961, s. $17-38$.

Wyczański A., Studia nad gospodarka starostwa korczyńskiego 1500-1660, Warszawa 1964, s. 58.

Żabko-Potopowicz A., Praca najemna i najemnik w rolnictwie w Wielkim Księstwie Litewskim w XVIII w., Warszawa 1929.

Żytkowicz L., Plony zbóż w Polsce, Czechach, na Wegrzech i Stowacji $w$ XVI-XVIII w., „Kwartalnik Historii Kultury Materialnej”, 18 (2), 1970, s. 227-253.

Żytkowicz L., Studia nad gospodarstwem wiejskim w dobrach kościelnych XVI w., Warszawa 1962.

Żytkowicz L., Ze studiów nad wysokościa plonów w Polsce od XVI do XVIII wieku, „Kwartalnik Historii Kultury Materialnej”, 14 (3), 1966 , s. $457-490$.

\section{Crop Yield in Royal Estates of the Polish Crown, 1564-1665}

\section{Summary}

The aim of this article is to present the structure, size and effectiveness of agricultural production in the royal manors between the year 1564 and 1665. The territorial scope covers the area of Lesser Poland, Greater Poland, Mazovia and Podlasie region. It should be noted that yields are one of the most important indicators of the productivity and economic development of pre-industrial Poland. An analysis of cereal production largely depends on the condition and type of preserved sources. For the Old Polish period, it is mainly lustrations of the royal estates which form the basis of the research. The core of the analysis is a quantitative method. In the present study, such measures as median, quartiles and LOESS regression are used, while the crop yield ratio was presented in the form of the so-called grain.
Research results reveal quite a poor picture of Polish agriculture. The sixteenth century was characterized by a large dispersion of the value of crop yields throughout the period, and we also note a considerable number of extreme values. Large fluctuations in yields meant the uncertainty of agricultural production results. In addition, each graph shows a downward trend: yields of four cereals (rye, oats, wheat, barley) reach the lowest value in the 1660s, due to war damage. In general, oats were characterized by the lowest yield, while barley, together with wheat, was the most efficient. In the sixteenth and seventeenth centuries, the lowest yields were recorded in Greater Poland, the highest in Mazovia and Podlasie. 
Monika Kozłowska-Szyc - historyk, doktorantka na Wydziale Historii i Stosunków Międzynarodowych Uniwersytetu w Białymstoku. Zainteresowania badawcze: historia społeczno-gospodarcza. Przygotowuje rozprawę doktorską podejmującą problematykę wpływu zmian klimatu na gospodarkę przedrozbiorowej Rzeczypospolitej (kozlmonika@gmail.com)

Monika Kozłowska-Szyc - historian, PhD student of the Faculty of History and International Affairs, University of Białystok; her research interests focus on socio-economic history; she works on her doctoral thesis about the influence of climate changes on the economy of the pre-partitioned Poland (kozlmonika@gmail.com) 